\title{
Sprouted wheat grain with ferritin overexpression as a potential source of iron for cereal product fortification
}

\author{
Magdalena Zielińska-Dawidziak • \\ Dorota Piasecka-Kwiatkowska $\cdot$ Jerzy R. Warchalewski • \\ Agnieszka Makowska $\cdot$ Magdalena Gawlak $\cdot$ Jan Nawrot
}

Received: 19 September 2013 / Revised: 28 December 2013 / Accepted: 29 December 2013 / Published online: 23 January 2014

(C) The Author(s) 2014. This article is published with open access at Springerlink.com

\begin{abstract}
Grains of winter wheat (Korweta variety) were partially germinated in an abiotic stress condition (0-15 $\mathrm{mM} \mathrm{FeSO}_{4}$ solutions) in order to accumulate iron by ferritin overexpression. The physical, chemical, biochemical properties and technological parameters of the obtained material as well as their resistance to an insect storage pest—granary weevil—were analyzed. Sprouted wheat grains with overexpression of ferritin contain 52 times more iron, more than $50 \%$ in form of ferritin. The contents of reducing sugars, crude protein, fiber and ash as well as amylolytic activity increased significantly in sprouted wheat grain, while starch, fat, wet gluten, falling number and inhibition activity against granary weevil $\alpha$-amylase decreased. Germinated wheat grain enriched with iron strongly affected granary weevil developmental parameters. Despite the fact that technological parameters of the product were deteriorated, it is worth to consider this material application as an iron supplement for cereal products, when the application of soybean is impossible.
\end{abstract}

M. Zielińska-Dawidziak ( $₫) \cdot$ D. Piasecka-Kwiatkowska · J. R. Warchalewski

Department of Food Biochemistry and Analysis, Poznań University of Life Sciences, ul. Mazowiecka 48, 60-623, Poznan, Poland

e-mail: mzd@up.poznan.pl

A. Makowska

Institute of Food Technology of Plant Origin, Poznań University of Life Sciences, ul. Wojska Polskiego 31, 60-624 Poznan, Poland

M. Gawlak · J. Nawrot

Institute of Plant Protection, National Research Institute, ul.

Władysława Węgorka 20, 60-318 Poznan, Poland
Keywords Ferritin · Iron · Sprouted wheat grain · Food fortification · Granary weevil

\section{Introduction}

Although iron is a microelement essential for the proper functioning of every organism, its deficiency in the human diet is high, concern on an average of $30 \%$ of the total population and in some specific periods, such as early childhood, pregnancy or menstruation is even up to $85 \%$ [1]. The food fortification in iron is one of the strategies of preventing anemia. However, this microelement supplementation is very complicated due to the free radicals formation possibility and differences in the absorption of various iron forms. In the prevention of iron deficiency, biofortification, e.g., increasing iron content of cereals and legumes seems to be promising [2].

Phytoferritin, a major iron storage protein, is a novel, natural and alternative dietary iron source. It is widely distributed in many legumes and cereals, namely green and yellow peas, red kidney beans, soybeans, lentils and corn [2]. The molecular structure of different origin ferritin is conserved and similar in animals, plants and microorganisms. The protein is constructed as a hollow sphere, 12- or 24-polypeptide, which surrounds the iron core. Apoferritin is able to store high amounts of iron, up to 4,500 atoms as a complex of $[\mathrm{FeO}(\mathrm{OH})]_{n}\left[\mathrm{FeO}\left(\mathrm{H}_{2} \mathrm{PO}_{4}\right)\right]$. This form is nontoxic and easily available for physiological requirement. Moreover, this protein is very stable in solution in denaturing conditions, e.g., temperature and some chemicals as well as on proteases activity. This suggests that ferritin survives digestion mostly, if not entirely intact [3].

The ferritin overexpression may be a good method for plant biofortification in iron. It can be achieved either by 
genetic transformation $[4,5]$ or by raising plant in stress conditions in high concentration of iron in growth environment $[6,7]$; however, both of these ways have some limitations. The first one, similar to other genetic crops modifications, is low acceptable in some societies. The second one often leads to obtaining degenerated plants. Nevertheless, not whole mature plants but only their parts or partially sprouted grains may be used for supplementation some food products.

Wheat grain is the most common cereal cultured all over the world, and therefore, it is a very significant source of dietary nutrients for people, particularly in the developing countries. Thus, in this study, some properties of partially sprouted, in stress condition, wheat grains were analyzed to examine the possibility of their use as a food supplement to flour, in order to fortify it in iron. It is well known that grains sprouting for a limited period causes an increase in hydrolytic enzymes activity, improvement in the contents of certain essential amino acids, total sugars, and B-group vitamins and a decrease in dry matter, starch, inhibitors of digestibility enzymes, flour yield and finally, baking quality [8-10]. From the nutritional point of view, the storage proteins and starch digestibility is improved and the nutritional value increases.

Very important features demonstrating the usefulness of cereal material for food industry are also their storage parameters. During storage, cereals are often infested by insects. The total losses caused by pests range from 10 to $30 \%$ of all storage grains. The most harmful granary weevil (Sitophilus granarius L.) itself incurred up to $5 \%$ of them. The degree of damage is directly related to the infestation rate determined by factors such as the number of eggs laid, and the offspring survival and fecundity. The cereal grains have natural resistance mechanisms to postharvest insects, depending on many factors. Among them, the most important are physicochemical and biochemical grain properties such as hardness, moisture, activity of inhibitors and extractable protein content [11-13]. Some of them are significant for insect from the nutritional point of view; another may play a role of attractant or repellent to post-harvest insects [11].

The purpose of this study was to investigate the influence of ferritin overexpression in partially germinated wheat grain on its physical, chemical, biochemical properties and technological parameters, as well as on the developmental parameters of granary weevil-the most dangerous grain pest.

\section{Materials and methods}

Winter wheat Korweta variety obtained from the Plant Breeding Station DANKO in Choryń (Poland) was used for this study. Prior to experiment, wheat grains were stored in tightly closed containers at $18{ }^{\circ} \mathrm{C}$.

Germination of grain for ferritin overexpression

Wheat grains were soaked in $70 \%$ ethanol solution for $15 \mathrm{~min}$ at $23{ }^{\circ} \mathrm{C}$ and then washed with tap water for $10 \mathrm{~min}$, four times with distilled water and soaked for 4 successive hours in $\mathrm{FeSO}_{4}$ solution in concentrations: 0, 1, 2.5, 5, 7.5, $10,12.5,15,17.5$ and $20 \mathrm{mM}$. Afterward, the grain samples were incubated in special germination dishes for 7 days at $23{ }^{\circ} \mathrm{C}$ in the dark. They were sprinkled everyday with $\mathrm{FeSO}_{4}$ solution with respective concentration and finally dried in a stream of circulating warm air $\left(\sim 40^{\circ} \mathrm{C}\right)$ down to $\sim 14 \%$ of moisture.

Total iron content in mineralized samples solution was determined using flame atomic absorption spectrometry with deuterium BC (Zeiss AAS-3, Jena). Samples were mineralized at $450{ }^{\circ} \mathrm{C}$ to obtain carbon-free white ash. Afterward, the ash was dissolved in $1 \mathrm{~N}$ nitric acid, filtered and analyzed. Total iron content in mineralized samples was determined by atomic absorption spectrometry $(\lambda=248.3$, slit of $0.15 \mathrm{~nm})$ [14].

Determination of ferritin iron content was carried out in accordance with the previously described procedure [6]. One gram of milled powder was extracted with $20 \mathrm{~mL}$ of $6 \mathrm{M} \mathrm{HCl}$ for $30 \mathrm{~min}$ at $80^{\circ} \mathrm{C}$. Extracted inorganic iron, not chelated and not introduced into organic compounds, was determined after thiocyanate reaction spectrophotometrically $(\lambda=480 \mathrm{~nm})$, at first as a free $\mathrm{Fe}^{3+}$ and after the oxidation reaction as a sum of $\mathrm{Fe}^{3+}$ and $\mathrm{Fe}^{2+}$ [15].

The difference between the content of the total iron and iron in form of ions $\left(\mathrm{Fe}^{2+}\right.$ and $\left.\mathrm{Fe}^{3+}\right)$ is considered to be the organic bounded iron (mainly the ferritin iron) content.

The following methods were used to determine the properties of obtained material, which was characterized by highest $\mathrm{Fe}^{2+}$ concentration:

- Crude protein content (Nx5.7), fat and ash content were carried out according to AACC methods [16].

- Starch content was determined by enzymatic method according to AACC Standard Method [17].

- Total crude fiber content was determined according to Scharrer-Kuerschner procedure [18].

- Kernel vitreosity (Polish Standard Method PN72/R-74008) [19].

- Thousand kernel weight (Polish Standard Method PN73/R-74017) [20].

- Falling number (AACC Standard Method 56-81-2000) [21].

- Gluten properties were carried out according to Polish Standard Method PN-77/A-7404 [22]. Gluten was washed-out by hand from whole milled sprouted grains. 
- Extracts were obtained in three-step water extraction $(1: 10 \mathrm{w} / \mathrm{v}, 1 \mathrm{~h})$ and analyzed for:

- Extractable protein content [23]

- Reducing sugar content according to the Hostettler and Daniel [24] method at $\lambda=530 \mathrm{~nm}$

- Amylolytic activity according Bernfeld method [25] at $\lambda=530 \mathrm{~nm}$

- Inhibitory activity against granary weevil (S. granarius L.) imago $\alpha$-amylase as described Warchalewski et al. [26].

\section{Entomological tests}

Wheat grain samples with ferritin overexpression and control grain were tested on their nutritional value for granary weevil. The beetles were collected from laboratory cultures, maintaining at $26{ }^{\circ} \mathrm{C}$ and $65 \%$ relative humidity and sexed by examining the rostrum and abdominal shape [27]. Fifty grains were placed in plastic vials $55 \mathrm{~mm}$ long by $25 \mathrm{~mm}$ in diameter and closed with a piece of cotton cloth. The grains were infested by 10 beetles ( 5 males and 5 females) of 5-10-day-old granary weevil. The test was conducted under controlled condition at $70 \%$ relative humidity, $26{ }^{\circ} \mathrm{C}$ in the dark. The beetles of granary weevil were removed after 5-, 10-, 20or 30-day of the feeding. Produced dust was weighted, and incubation of grain samples were continued until full development time was completed. The mean number of adult progeny and the mean development time were used to calculate an index of varietal susceptibility [28]. Vials were checked daily from 36 until 64 days of the experiment for emerged progeny adult to determine progeny numbers and full development time. All experiment was replicated five times and was carried out similar to that described by Fornal et al. [29].

\section{Statistical analysis}

The obtained results were subjected to statistical analysis and the data were expressed as the mean with standard deviation. One-way analysis of variance (ANOVA) was applied to study significant differences in the analyzed properties of germinated and non-germinated grain. The post hoc Tukey's test was used to analyze differences and determine homogenous groups. Shapiro-Wilk test was used to examine the normality assumption, and Levene test to verify variance homogeneity. The data were analyzed with the use of Statistica 8.0 software and all tests were considered significant at $P<0.05$. Every experiment was three times repeated with the exception of entomological tests (see above).

\section{Results and discussion}

Wheat grains germination was conducted in the aqueous solution of ferrous sulfate at different concentrations. The main purpose of this experiment was to receive the highest level of iron accumulation, most of it in ferritin form. Therefore, the experiment was carried out in abiotic stress conditions in order to increase the overproduction ferritin [30], which both protects plants against stress conditions and, simultaneously, cumulates the iron. It was not so important to achieve a completely germinated grain. The length of obtained sprouts was strongly reduced; however, grains were still viable and the sprouts growth was observed. The results of iron contents analysis in dried, germinated in $0-15 \mathrm{mM} \mathrm{FeSO}_{4}$ solutions wheat grain are presented in Fig. 1. The solution containing $15 \mathrm{mM}$ of $\mathrm{Fe}^{2+}$ was the last one, which allowed the germination processes and, simultaneously, gave the highest level of bounded iron, making obtained material potentially the best source of this microelement. The complexed iron (i.e., ferritin iron) content in this probe reached $\sim 53 \%$ of total iron content (Fig. 2). The main cation of ionic iron was $\mathrm{Fe}^{2+}$ $(\sim 40.5 \%)$, and the rest was $\mathrm{Fe}^{3+}$ ion. It must be emphasized that whole iron was determined, including iron associated with the grain surface, not only this incorporated in the structure of the grain cells. The results were similar to those obtained for another variety of wheat (data not presented). For this reason, only one variety was chosen for the rest of the analysis, the Korweta variety.

Much better results in ferritin overexpression were obtained for legumes, both in total iron content and in ferritin iron content [6]. However, the legumes are the fifth most prevalent food allergens, and for the big part of population, their consumption as food components is prohibited

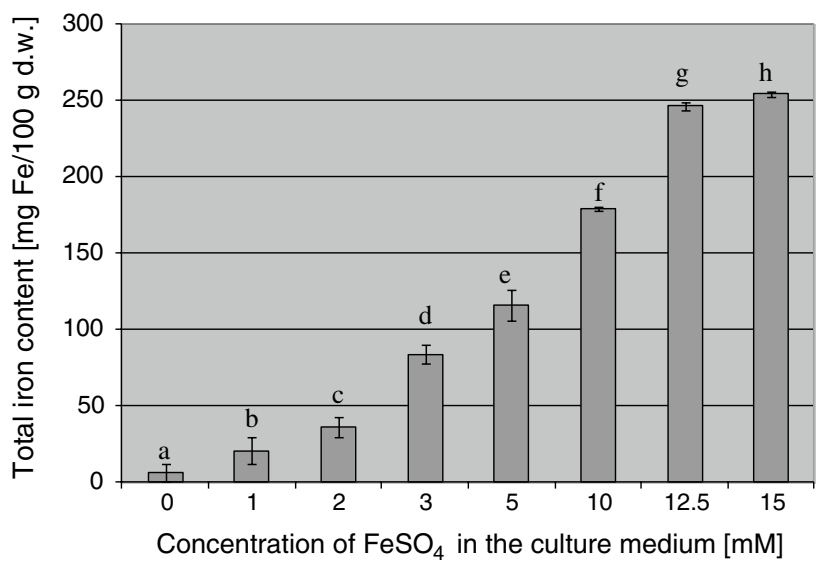

Fig. 1 Accumulation of iron in Korweta sprouted grains after 7 days of their cultivation in $0-15 \mathrm{mM}$ of $\mathrm{FeSO}_{4}$. Different letters indicate statistically significant differences at $P<0.05$ 


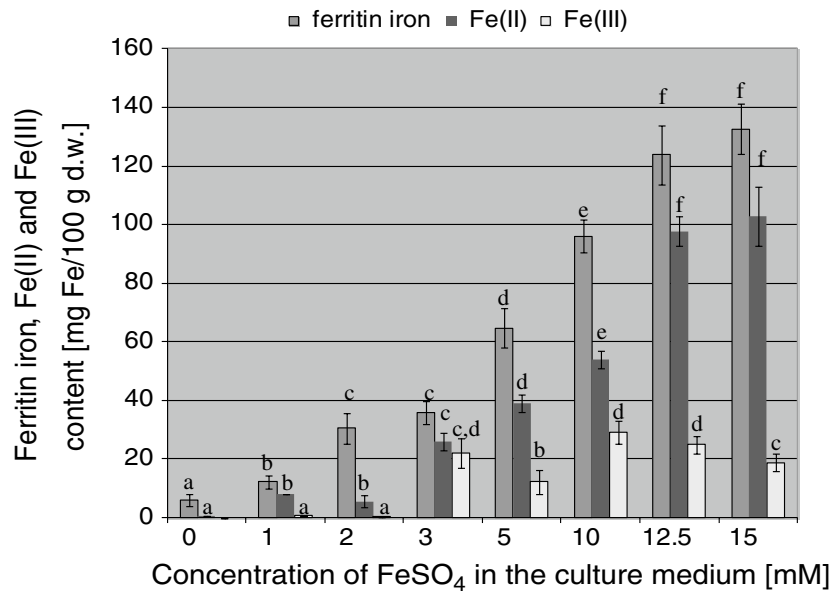

Fig. 2 Ferritin iron and ionic iron content in Korweta sprouted grains after 7 days of their cultivation in $0-15 \mathrm{mM}$ of $\mathrm{FeSO}_{4}$. Different letters indicate statistically significant differences at $P<0.05$

[31]. The use of fortified-in-iron germinated cereals may be an alternative. Increased ferritin iron content is the crucial aspect of the proposed preparation. Even if the bioavailability of the $\mathrm{FeSO}_{4}$ is on the same level, ferritin iron is absorbed with different mechanism, with another transporter than divalent cations [32]. Thus, it may be designed to the person with the impaired iron absorption mechanism. Moreover, ferritin iron, trapped in the protein shell, does not discolor the food and children teeth and does not cause gastric problems, and their redox reactivity is limited [33].

During germination, enzymes in grains are very active; they change grains chemical composition even if the level of sprouting is very low. Therefore, the composition of the grain sprouted in $15 \mathrm{mM}$ was analyzed to characterize its suitability for fortification of cereal products.

In Table 1, main chemical, biochemical and physical properties of Korweta variety wheat grain germinated in stress condition of $15 \mathrm{mM} \mathrm{FeSO}_{4}(\mathrm{KFe})$ are compared with not germinated, control grain sample $(K)$. Strong stress conditions used in the experiment significantly affected the chemical composition of the obtained research material.

Starch and fat are the main reservoirs of energy for biosynthesis during germination; thus, it is obvious that decrease in their contents were noted ( 4 and $\sim 16 \%$, respectively). The increase in reducing sugar content by 14 times is also evident due to the $36 \%$ increase in amylolytical activity.

Protein hydrolysis during germination usually increases their digestibility, and peptides or amino acids content. However, statistical difference in the extractable protein content was not observed in examined material. It may be stated that expression of some new proteins, among these ferritin, as a result of a high abiotic stress occurs together with the partially protein hydrolysis. This assumption is supported by a noted increase in crude protein content determined according to Kjeldahl method. These results are different from those presented before. A small decrease or no changes in crude protein content and an increase in non-protein nitrogen and free amino acids content in seeds sprouted in water were usually observed [34-36].

Some reports inform about an increase, while others about a decrease in minerals content in sprouted seeds [37, $38]$ as well as in fiber content [39, 40]. Received in this

Table 1 Effect of germination in stress condition $\left(15 \mathrm{mM} \mathrm{FeSO}_{4}\right)$ on chemical, biochemical and physical properties of Korweta variety wheat grain

\begin{tabular}{|c|c|c|c|}
\hline Wheat variety & Unit & Korweta grain & Sprouted in $15 \mathrm{mM}$ \\
\hline Total iron content & mg/100 g d.wt. & $5.63 \pm 3.09^{\mathrm{a}}$ & $254.30 \pm 1.7^{\mathrm{b}}$ \\
\hline Crude protein & $\%$ d.wt. & $12.60 \pm 0.05^{\mathrm{a}}$ & $13.92 \pm 0.22^{\mathrm{b}}$ \\
\hline Fat & $\%$ d.wt. & $2.12 \pm 0.12^{\mathrm{b}}$ & $1.79 \pm 0.07^{\mathrm{a}}$ \\
\hline Starch & $\%$ d.wt. & $61.80 \pm 0.48^{\mathrm{b}}$ & $59.60 \pm 0.26^{\mathrm{a}}$ \\
\hline 1,000 kernel mass & $\mathrm{g}$ & $44.31 \pm 0.24^{\mathrm{a}}$ & $53.94 \pm 0.12^{\mathrm{b}}$ \\
\hline Vitreosity & $\%$ & $81 \pm 1^{\mathrm{b}}$ & $0 \pm 0^{\mathrm{a}}$ \\
\hline Ash & $\%$ d.wt. & $1.72 \pm 0.06^{\mathrm{a}}$ & $2.10 \pm 0.03$ \\
\hline Dietary fiber & $\%$ d.wt. & $2.35 \pm 0.08^{\mathrm{a}}$ & $3.41 \pm 0.05^{\mathrm{b}}$ \\
\hline Reducing sugar & $\%$ d.wt. & $0.51 \pm 0.01^{\mathrm{a}}$ & $6.95 \pm 0.11^{\mathrm{b}}$ \\
\hline Extractable protein & $\%$ d.wt. & $2.385 \pm 0.20^{\mathrm{a}}$ & $2.406 \pm 0.10^{\mathrm{a}}$ \\
\hline Total amylolytic activity & $\begin{array}{l}\text { Total units } / 100 \mathrm{~g} \text { d.wt. } \\
\text { Specific units/mg extract. protein }\end{array}$ & $\begin{array}{l}13,620 \pm 580^{\mathrm{a}} \\
5.7 \pm 0,2^{\mathrm{a}}\end{array}$ & $\begin{array}{l}18,513 \pm 480^{\mathrm{b}} \\
7.7 \pm 0,2^{\mathrm{b}}\end{array}$ \\
\hline Inhibitory activity against $S$. granarius $\alpha$-amylase & $\begin{array}{l}\text { Total antiunits } / 100 \mathrm{~g} \text { d.wt. } \\
\text { Specific antiunits/mg extract. protein }\end{array}$ & $\begin{array}{l}201,971 \pm 5,987^{\mathrm{a}} \\
84.8 \pm 2.5^{\mathrm{b}}\end{array}$ & $\begin{array}{l}163,978 \pm 5,914^{b} \\
68.12 \pm 2.5\end{array}$ \\
\hline
\end{tabular}

d.wt., dry weight

Different index letters show statistically significant differences at $P<0.05$ 
study germinated grains contain $45 \%$ more of crude fiber than the control ones, which may be an additional dietary benefit. The iron content in $\mathrm{KFe}$ significantly increased, as it was expected. The substantial increase in iron was over 52 times more than that determined in the control sample. It also resulted in a higher level of ash in KFe samples.

The obtained in stress conditions $\left(15 \mathrm{mM} \mathrm{FeSO}_{4}\right)$, partially germinated grain may be considered as a possible source of iron in food fortification. It should be expected that this iron is mainly gathered in a hull [1]. Therefore, the whole ground grains of germinated wheat grain should be taken for the purpose of supplementation. The proposed conditions could change also the milling properties of the examined material. The grain physical parameters, such as the 1,000 kernel weight and vitreousness, are more important for milling than their chemical composition [41]. In KFe samples, $22 \%$ increase in the 1,000 kernel weight was noted, as well as a complete change in sprouted grain vitreous character (Table 1). Due to the increase in enzyme activity, the endosperm structure was altered and slight air spaces could appear between endosperm cells. These air spaces caused that the observed grains were neither gray nor vitreous, but white and defined as mealy.

Chemical, physical and biochemical properties induced during germination under stress conditions also affected some values of technological parameters (Table 2). The most significant for the bakery industry is both gluten quantity and its quality. All analyzed gluten parameters of flour KFe disqualify it as a raw material for bread production. Falling number is also crucial flour quality parameter

Table 2 Influence of germination in stress condition (15 $\left.\mathrm{mM} \mathrm{FeSO}_{4}\right)$ on some technological parameters of received $\mathrm{KFe}$ flour

\begin{tabular}{ll}
\hline Percentage decrease & $\%$ \\
\hline Wet gluten & 25 \\
Wet gluten spreadability & 67 \\
Gluten index & 20 \\
Falling number & 75 \\
\hline
\end{tabular}

from the technological point of view. It is used to measure the amylase activity impact on starch damage. Generally, the falling number value of $350 \mathrm{~s}$ or higher indicates a low enzyme activity and the flour uselessness for baking. Values below $200 \mathrm{~s}$ show high levels of enzyme activity and limit the possibility of its usage [42].

The falling number of $\mathrm{KFe}$ fourfold decreased compare to Korweta suggesting enormous damage of starch caused by amylases high activity (Table 2). This was supported by a $36 \%$ increase in endogenous amylase activity as well as 14 times more reducing sugar content (Table 1). As it was expected, grain germination deteriorated all determined values of technological parameters (Table 2), which clearly indicates limited usefulness of flour $\mathrm{KFe}$ for bread making. However, due to the high iron content, KFe may be used only as an additive to flour. Less than $3 \mathrm{~g}$ of this supplement introduced into $100 \mathrm{~g}$ portion of meal supplies $\sim 50 \%$ of the daily iron requirement in a diet, which is a dose recommended by European law [43]. Moreover, it was noted before that the ferritin is resistant to baking processes [44].

Sprouted grains and seeds were also proposed before as a supplement to pasta, e.g., flour obtained from germinated pigeon peas up to $10 \%$ in semolina flour [45]. The enrichment of pasta in sprouts increased the contents of protein, available sugars, dietary fiber, vitamins $\left(B_{2}, E\right.$ and $\left.C\right)$ and reduces antinutritional substances, such as trypsin inhibitors and lipoxygenases [46, 47]. Due to worst technological parameters of germinated grain with ferritin overexpression, their usage as a supplement to pasta flour may be an ideal alternative. It should be emphasized that the temperature of pasta drying process and a short time of pasta cooking reduce the possibility of ferritin denaturation, simultaneously protecting iron from oxidation and decrease in its availability. Another use could be an addition of the material to various kinds of extruded products. In this case, the flour enzyme activity is not a problem, because amylolytic activity does not influence negatively on the quality of these products [47].

The use of a new additive to bakery products and pasta is always connected with their storage problems. Germinated

Table 3 Development parameters of the granary weevil on non-sprouted $(K)$ and sprouted under stress condition wheat grain $(\mathrm{KFe})$ Korweta variety

\begin{tabular}{|c|c|c|c|c|c|c|c|c|}
\hline \multirow[t]{2}{*}{ Time of infestation (days) } & \multicolumn{2}{|c|}{ Development time (days) } & \multicolumn{2}{|c|}{ Progeny number (pcs) } & \multicolumn{2}{|l|}{ Dust (mg) } & \multicolumn{2}{|c|}{$\begin{array}{l}\text { Index of varietal suscep- } \\
\text { tibility }\end{array}$} \\
\hline & $K$ & $\mathrm{KFe}$ & $K$ & $\mathrm{KFe}$ & $K$ & $\mathrm{KFe}$ & $K$ & $\mathrm{KFe}$ \\
\hline 5 & $44 \pm 1^{\mathrm{a}}$ & $49 \pm 1^{b}$ & $24 \pm 4^{\mathrm{b}}$ & $1 \pm 2^{\mathrm{a}}$ & $6.0 \pm 0,2^{\mathrm{a}}$ & $9.04 \pm 1.6^{\mathrm{b}}$ & $7.3 \pm 0.5^{\mathrm{b}}$ & $2.5 \pm 0.3^{\mathrm{a}}$ \\
\hline 10 & $44 \pm^{\mathrm{a}}$ & $54 \pm 1^{\mathrm{b}}$ & $41 \pm 4^{b}$ & $23 \pm 6^{\mathrm{a}}$ & $11.4 \pm 0,5^{\mathrm{a}}$ & $14.48 \pm 1.2^{\mathrm{b}}$ & $8.5 \pm 0.3^{\mathrm{b}}$ & $5.8 \pm 0.5^{\mathrm{a}}$ \\
\hline 20 & $48 \pm 1^{\mathrm{a}}$ & $60 \pm 2^{b}$ & $48 \pm 2^{b}$ & $32 \pm 1^{\mathrm{a}}$ & $21.4 \pm 1.4^{\mathrm{a}}$ & $23.70 \pm 2.3^{\mathrm{b}}$ & $8.1 \pm 0.2^{\mathrm{b}}$ & $5.8 \pm 0.2^{\mathrm{a}}$ \\
\hline 30 & $51 \pm 1^{\mathrm{a}}$ & $62 \pm 2^{b}$ & $53 \pm 2^{\mathrm{b}}$ & $42 \pm 6^{\mathrm{a}}$ & $49.8 \pm 6.9^{b}$ & $32.48 \pm 2.1^{\mathrm{a}}$ & $7.8 \pm 0.1^{\mathrm{b}}$ & $6.1 \pm 0.2^{\mathrm{a}}$ \\
\hline
\end{tabular}

Different index letters show statistically significant differences at $P<0.05$ 
grain is more susceptible to rancidity and microbial infection. Proper drying of the obtained material (down to $15 \%$ moisture content) limits these changes (data not shown). However, enormous problem during the grain storage are losses caused by storage pests. Thus, this grain susceptibility to insect infestation should be analyzed. Changes in chemical composition can stimulate or inhibit insects feeding. If the iron accumulation in wheat hull hinders the development of insects, the proposed process of wheat grain germination will have an additional positive result. Therefore, entomological tests were conducted on S. granarius $\mathrm{L}$., one of the most harmful pest for stored cereals.

The inhibitory activity of wheat grain against $\alpha$-amylase of the granary weevil should be considered as a resistant factor in response to the main insect digestive enzyme [11]. However, highly active insect $\alpha$-amylase inhibitors appear to have limited influence on development parameters of $S$. granarius L.; nevertheless, some reduction in insect population might be expected [48]. The decrease by $19 \%$ in inhibition activity against $S$. granaries $\alpha$-amylase in $\mathrm{KFe}$ is a little disturbing (Table 1). Though, some metal ions may work as a strong inhibitor or an activator of insects growth $[49,50]$. Table 3 presents granary weevil development parameters on non-sprouted and sprouted wheat Korweta grain.

High intensity of weevil feeding on KFe grain samples was observed up to the first 10 days of the experiments. Probably, due to lower vitreosity and hardness, it was easier for insects to bite into. For this reason, dust production after 5-feeding days almost doubled. Prolonged time of feeding up to 30th day on KFe resulted in $43 \%$ decrease of dust production comparing to non-germinated Korweta grain. A longer feeding period extended the time of granary weevil development from 20 to $30 \%$ and progeny number was also significantly lower. The grain susceptibility index [51], which includes the number of progeny produced and development time, is a proper method to compare desirability of various grains by insects. In this experiment, the index for $\mathrm{KFe}$ was 5.0, whereas for $\mathrm{K}$, it was 7.9. This confirms higher resistance of wheat grains with ferritin overexpression to granary weevil infestation. It could be expected that the obtained material should have a good resistance to storage pests.

\section{Concluding remarks}

Partially germinated under stress condition, wheat grain accumulates 52 times more iron than non-germinated one. Therefore, this germinated grain with ferritin overexpression is a beneficial for cereal products supplementation. Deteriorated technological parameters should not significantly influence bread, pasta and extrusion products making, because the level of additive should not exceed $\sim 3 \%$. Germinated grain rich in iron characterize increased resistance against granary weevil infestation.

The obtained material, because of increased ferritin content, is promising iron supplement. Future work should be focused on stability of the ferritin in processed food and its bioavailability.

Acknowledgments This work was supported by research Grant No. N312 029 31/2098.

\section{Conflict of interest None.}

Compliance with Ethics Requirements This article does not contain any studies with human or animal subjects.

Open Access This article is distributed under the terms of the Creative Commons Attribution License which permits any use, distribution, and reproduction in any medium, provided the original author(s) and the source are credited.

\section{References}

1. Theil EC (2004) Iron, ferritin, and nutrition. Annu Rev Nutr 24:327-343

2. Zhao G (2010) Phytoferritin and its implications for human health and nutrition. Biochim Biophys Acta 1800:815-823

3. Theil EC, Briat J-F (2004) Plant ferritin and non-heme iron nutrition in humans. Int Food Policy Res Inst 1:1-13

4. Goto F, Yoshihara T, Shigemoto N, Toki S, Takaiwa F (1999) Iron fortification of rice seed by the soybean ferritin gene. Nat Biotech 17:282-286

5. Lucca P, Hurrell R, Potrykus I (2001) Genetic engineering approaches to improve the bioavailability and the level of iron in rice rains. Theor Appl Genet 102:392-397

6. Zielińska-Dawidziak M, Siger A (2012) Effect of elevated accumulation of iron in ferritin on the antioxidants content in soybean sprouts. Eur Food Res Technol 234:1005-1012

7. Lonnerdal B (2003) Genetically modified plants for improved trace element nutrition. J Nutr 133:1490-1493

8. Chavan JK, Kadam SS (1989) Nutritional improvement of cereals by sprouting. Crit Rev Food Sci Nutr 28:401-437

9. Kruger JE (1994) In: Bushuk W, Rasper V (eds) Wheat: production, properties and quality. Blackie Academic and Professional, Glasgow

10. Neethirajan S, Jayas DS, White NDG (2007) Detection of sprouted wheat grains using soft X-ray image analysis. J Food Eng 81:509-513

11. Nawrot J, Warchalewski JR, Piasecka-Kwiatkowska D, Niewiada A, Gawlak M, Grundas ST, Fornal J (2006) The effect of some biochemical and technological properties of wheat grain on granary weevil (Sitophilus granarius L.) (Coleoptera: carciulionidae) development. In: Proceedings of the 9th international working conference on stored product protection. Associação Brasileira De Pós-Colheita, Campinas, pp 401-407

12. Mebarkia A, Guechi A, Mekhalif S, Makhlouf M (2009) Biochemical composition effect of the some cereal species' on the behaviour of Sitophilus granarius L. and Rhyzopertha dominica F. species in semi-arid zone of Setif, Algeria. J Agron 8:60-66

13. Nawrot J, Gawlak M, Szafranek J, Szafranek B, Synak E, Warchalewski JR, Piasecka-Kwiatkowska D, Błaszczak W, Jeliński T, 
Fornal J (2010) The effect of wheat grain composition, cuticular lipids and kernel surface microstructure on feeding, egg-laying, and the development of the granary weevil, Sitophilus granarius (L.). J Stored Prod Res 46:133-141

14. Tsalev DL (1984) In: Tsalev DL, Zaprianov ZK (eds) Atomic absorption spectrometry in occupational and environmental healths practice: determination of individual elements. CRC Press, Boca Raton

15. Sandell EB (1959) Colorimetric determination of traces of metals, 3rd edn. Interscience Publishers Inc, New York

16. AACC International (1999) Approved methods of analysis, 11th edn. Method 46-10.01 (ARCHIVED) crude protein-improved kjeldahl method. AACC International, St. Paul, MN

17. AACC International (1999) Approved methods of analysis, 11th edn. Method 76-13.01. Total starch assay procedure (megazyme amyloglucosidase/ $\alpha$-amylase method. AACC International, St. Paul, MN

18. Van Soest PJ, Robertson JB, Lewis BA (1991) Methods for dietary fiber, neutral detergent fiber, and nonstarch polysaccharides in relation to animal nutrition. J Diary Sci 74:3583-3597

19. Polish Standard Method PN-72/R-74008 — kernel vitreosity

20. Polish Standard Method PN-73/R-74017-thousand kernel weight

21. AACC International (1999) Approved methods of analysis, 11th edn. Method 56-81.03 determination of falling number. AACC International, St. Paul, MN

22. Polish Standard Method PN-A-74041:1977-determination of gluten quantity and quality

23. Lowry OH, Rosebrough NJ, Farr JL, Randall RJ (1951) Protein measurement with the Folin phenol reagent. J Biol Chem 193:265-275

24. Hostettler FB, Denel H (1951) Uber die reduction der 3,5-DNS durch zuker. Helv CIANN Acta 34:2132

25. Bernfeld O (1955) In: Colowick SO, Kaplan NO (eds) Methods in enzymology (I). Academic Press, New York

26. Warchalewski JR, Madaj D, Skupin J (1989) The varietal differences of some biological activities of proteins extracted from flours of wheat seeds harvested in 1986. Nahrung 33:805-821

27. Halstead DGH (1963) External sex differences in stored product Coleoptera. Bull Entomol Res 54:19-34

28. Dobie P (1973) Laboratory assessment of the inherent susceptibilities of 25 variety of Malawi maize to postharvest infestation by Sitophilus zeamais Motsch (Coleoptera: Curculionidae). Trop Prod Inst L33:1-16

29. Fornal J, Jeliński T, Sadowska J, Grundas S, Nawrot J, Niewiada A, Warchalewski JR, Błaszczak W (2007) Detection of granary weevil Sitophilus granarius (L.) eggs and internal stages in wheat grain using soft X-ray and image analysis. J Stored Prod Res 43:142-148

30. Briat JF (1996) Roles of ferritin in plants. J Plant Nutr 19: $1331-1342$

31. Wang J (2009) In vitro and in vivo cross-reactivity studies of legume allergy in a Mediterranean population. Pediatricsdigest 124:S123

32. San Martin CD, Garri C, Pizarro F, Walter T, Theil EC, Núñez MT (2008) Caco-2 intestinal epithelial cells absorb soybean ferritin by mu2 (AP2)-dependent endocytosis. J Nutr 138: 659-666

33. Hurrel RF (2002) Fortification: overcoming technical and practical barriers. J Nutr 132:806-812
34. King RD, Puwastien P (1987) Effect of germination on the proximate composition and nutritional quality of winged beans (Psophocarpus tetragonolbo) seeds. J Food Sci 52:106-108

35. Kozłowska H, Zieliński H, Buciński A, Piskała MK (2003) Biologically active components of rapeseed sprouts. Oilseed Crops 24:23-31

36. Sangronis E, Camacho CJ, Cava R (2004) Propiedades funcionales de las harinas de leguminosas (Phaseolus vulgaris y Cajanus cajan) germinadas. Interciencia 29:80-85

37. Camacho L, Sierra C, Campos R, Guzmān E, Marcus D (1992) Cambios nutricionales inducos por la germination de leguminosas de consumo habital en Chile. Arch Latinoam Nutr 42:283-290

38. Kavas A, El Nehir S (1992) Changes in nutritive value of lentils and mung beans during germination. Chem Mikrobiol Technol Lebensmittel 14:3-9

39. Chitra U, Singh U, Rao PV (1996) Phytic acid, in vitro protein digestibility, dietary fiber and mineral of pulse as influenced by processing methods. Plant Foods Hum Nutr 49:307-316

40. Martin-Cabrejas MA, Ariza N, Esteban R, Mollā E, Waldron K, Lōpez-Andreu F (2003) Effect of germination on the carbohydrate composition of the dietary fiber of peas (Pisum sativum L.). J Agric Food Chem 51:1254-1259

41. Grundas S, Skubisz G (2008) Physical properties of cereal grain and rape stem. Res Agric Eng 54:80-90

42. Kent NL, Evers AD (1994) Flour quality. In: Kent NL, Evers AD (eds) Kent's technology of cereals, 4th edn. Pergamon Press, Oxford

43. Recommendation Of The European Parliament And Of The Council of 18 December 2006 on key competences for lifelong learning (2006/962/EC). Off J Eur Union. 30 Dec 2006

44. Beard JA, Burton JW, Theil EC (1996) Purified ferritin and soybean meal can be sources of iron for treating iron deficiency in rats. J Nutr 126:154-160

45. Torres A, Frias J, Granito M, Vidal-Valverde C (2007) Germinated Cajanus cajan seeds as ingredients in pasta products: chemical, biological and sensory evaluation. Food Chem 101:202-211

46. Kumar V, Rani A, Pandy V, Chauhan GS (2006) Changes in lipoxygenase isozymes and trypsin inhibitor activity in soybean during germination in different temperatures. Food Chem 99:563-568

47. Antila J, Seiler K, Seibel W, Linko P (1983) Production of flat bread by extrusion cooking using different wheat/rye ratios, protein enrichment and grain with poor baking ability. J Food Eng 2:189-210

48. Warchalewski JR, Gralik J, Winiecki Z, Nawrot J, PiaseckaKwiatkowska D (2002) The effect of wheat $\alpha$-amylase inhibitors incorporated into wheat-based artificial diets on development of Sitophilus granarius L.; Tribolium confusum Duv.; Ephestica kuehniella Zell. J Appl Entomol 126:161-168

49. Jaworska M, Ropek D, Tomasik P (1999) Chemical stimulation of productivity and pathogenicity of entomopathogenic nematodes. J Invertebr Pathol 73:228-230

50. Morgan TD, Baker P, Kramer KJ, Basibuyuk HH, Quicke LJ (2003) Metals in mandibles of stored product insects: do zinc and manganese enhance the ability of larvae to infest seeds? J Stored Prod Res 39:65-75

51. Dobie P (1974) The laboratory assessment of the inherent susceptibility of maize varieties to post-harvest infestation by Sitophilus zeamais Motsch (Coleoptera: Curculionidae). J Stored Prod Res 14:87-93 